\title{
Study of mechanical properties of C-Mn-Si composition metal after wire-arc additive manufacturing (WAAM)
}

\author{
A. E. Balanovskiy, Cand. Eng., Associate Prof. ${ }^{1}$ \\ N. A. Astafyeva, Cand. Eng., Associate Prof. ${ }^{1}$ \\ V. V. Kondratyev, Cand. Eng., Senior Scientific Researcher ${ }^{2}$ \\ A. I. Karlina, Cand.Eng., Scientific Researcher ${ }^{3}$,e-mail: karlinat@mail.ru
}

\author{
${ }^{1}$ Irkutsk National Research Technical University, Irkutsk, Russia \\ ${ }^{2}$ A. P. Vinogradov Institute of Geochemistry of the Siberian Branch of the Russian Academy of Sciences, Irkutsk, Russia \\ ${ }^{3}$ Moscow State University of Civil Engineering, Moscow, Russia
}

\begin{abstract}
Wire-arc additive manufacturing (WAAM) is considered as a rather promising alternative to conventional subtracting production process for manufacture of large expensive metal components with complicated geometrical shape. Up-todate direction of WAAM investigations is aimed on production of functional metallic components with complicated geometrical shape and high accuracy, surface processing and mechanical properties meeting the strict requirements of aerospace, automotive and instrumental industries. At the same time, structural application of metal components based on their mechanical properties is studied insufficiently. It is necessary to understand additionally influence of technological conditions (such as energy input, protective gas role, speed of wire feed, welding speed, facing features and its sequence etc.) on the thermal initial parameters and finishing mechanical properties. The paper displays that mechanical properties of low-alloyed silicon-manganese composition of $\mathrm{C}-\mathrm{Mn}$-Si type with ferrite-pearlite structure is higher comparing with conventional steel 09G2S. It is shown that impact strength values for C-Mn-Si-type composition, which id formed via WAAM method, is higher by 2 times in comparison with welded joints which are faced by Sv-08G2S wire.

Key words: Wire-arc additive manufacturing (WAAM), metal 3D printing technologies, low-carbon steel, structure, hardness, mechanical properties, extension, impact strength.

DOI: $10.17580 /$ cisisr.2021.02.12
\end{abstract}

\section{Introduction}

Evaluation of the importance of additive production(AM or 3D printing) was carried out during several last decades [1-10]. AM is the technology which promises to decrease cost of components due to cutting the material wastes and time of entering the market [1,2]. Conventional AM methods include laser [3, 4], electron beam [5] and electric arc [6-10] as heat sources. Both laser and electron beam technologies are widely used in various industries for manufacture of functional and structural components with complicated structural shape [3-5]. Wire-arc additive manufacture (WAAM) uses electric arc as heat source and solid wire as initial material [11, 12]. WAAM is the method of additive manufacture, which uses arc welding for metal wire melting. Wire is applying by layers with assistance of robotic manipulator, in correspondence with a 3D model; as a result, high-precision billet for consequent processing in CNC machine tool is obtained. Manufacture of defect-free billets with excellent physical, mechanical and metallurgical properties is one of the tasks of additive manufacturing (AM) of metal materials [11, 12]. Most of modern commercial metal materials which are used for AM are steels [4-7, 10, 11], as well as aluminium and titanium alloys [13-18]. It is necessary to analyze influence of technological conditions on thermal "history", microstructure and finishing mechanical and surface properties of components during wire and arc additive manufacturing. At present time there are many works describing WAAM use in manufacture of different products. However, the problems of control on metal mechanical properties in the manufactured product are still not solved completely. In conventional production, mechanical properties of rolled products are well-known and are preset by metal producers, while in the case of additive production we are aware only about chemical composition of powder and wire for further manufacture of finished products. E.g., low-alloyed silicon-manganese structural steels with ferrite-pearlite structure are widely used for different components and details of heavy-duty welded metal constructions (i.e. for cold-resistant purposes). Many components of constructions and mechanisms can be manufactured using WAAM [19, 20]. So, metal forgings with length about $2.2 \mathrm{~m}$, weight $260 \mathrm{~kg}$ and surface roughness $0.02 \mathrm{~mm}$ were produced via the additive arc process and described in [19]. Fabrication of the crane arm using WAAM technology is presented in [20].

Existence of tough-brittle (T-B) transition connected with toughness temperature relationship is a fundamental feature of low-alloyed steels. It is stipulated by the fact that microstructure of these steels contains mainly ferrite components with BCC-lattice. However, more deep understanding of mechanical properties of materials obtained for this type of facing is required previously to the time when production of reliable components for critical loads via WAAM technique will become the main technological direction. This research includes examination of metal mechanical properties for low-alloyed C-Mn-Si composition, while this metal was formed in the process of wire-arc additive manufacturing. Obtaining of the new material of low-alloyed C-Mn-Si composition, formed during WAAM, which differs from 

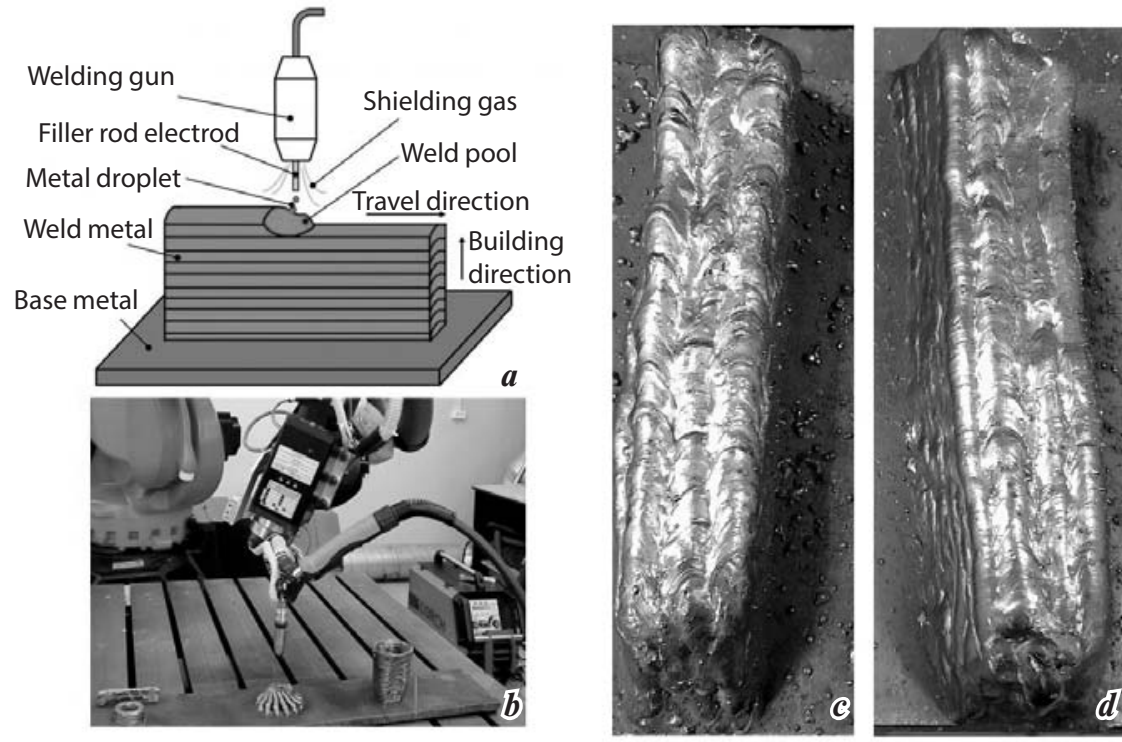

KR 210 R2700 prime, welding machine Lorch SpeedPulse S3 mobil, balloon with protective gas $\mathrm{CO}_{2}$ and gas mix $\left(\mathrm{Ar}+\mathrm{CO}_{2}\right)$. Wire facing was carried out via the method of gas metal arc welding (GMAW). Each layer is forming during one pass by one roll of facing metal. Faced walls of samples for mechanical testing were conducted using protective gas $\mathrm{CO}_{2}$ (Fig. 1c) and gas mix $\left(\mathrm{Ar}+\mathrm{CO}_{2}\right)$ (Fig. 1d). Structure investigation for metal of formed wall was carried out using welding wire Sv-08G2S and was compared with strip structure of conventional 09G2SA steel. Microstructure of metal of formed wall was examined using microscope MicroMed 2, digital microscope Olympus GX41 A (with magnification $\times 500, \times 100, \times 200, \times 500$ and $\times 1000$ ).

Electronic microscope investigations were conducted using electronic microscope JIB-4501 JEOL. Chemical

conventional metallurgical production technology, can be considered as the scientific novelty of this research.

\section{Materials and methods of the research}

Welding wire Sv-08G2S with diameter $0.8 \mathrm{~mm}$ according to the GOST 2246-70 was used as main material for forming the semiproduct of the component (Fig. 1). WAAM scheme is displayed on the Fig. $1 a$, while Fig. $1 b$ shows fabricated details of impeller, cup and cylinder. However, this finished product (Fig. $1 b$ ) is characterized by unknown mechanical properties. Sheet rolled metal of $09 \mathrm{G} 2 \mathrm{~S}$ steel (according to the GOST 19281-2014) with the most close chemical composition to $\mathrm{C}-\mathrm{Mn}$-Si composition was used for comparison with the properties of material manufactured using welding wire Sv-08G2S of C-Mn-Si composition via additive technology. This steel is related to the group of low-alloyed silicon-manganese structural steels. Wire facing was applied on steel plate with thickness $16 \mathrm{~mm}$. Semiproducts of C-Mn-Si composition with size $40 \times 50 \times 200 \mathrm{~mm}$ were obtained during facing. Robotic technical complex which was mounted in Irkutsk National Research Technical University (Fig. 1b) was used as an industrial 3D printer. This robotic complex includes industrial robot KUKA composition was determined with assistance of optical emission spectrometer PMI-MASTER UVR. Conduction of testing for static extension according to the GOST 1497-84 included the following parameters of seam metal: tensile strength, $\mathrm{N} / \mathrm{mm}^{2}$; yield strength, $\mathrm{N} / \mathrm{mm}^{2}$; relative elongation, \%; relative reduction of area, $\%$. Metal testing was carried out at the temperature $+20{ }^{\circ} \mathrm{C}$, flat samples of I type were used. Processing, analysis and evaluation of the testing results were conducted in accordance with the GOST 6996-66 and GOST 1497-84. Impact toughness (KCU) of the metal formed via additive technology was determined in impact bending testing on samples with U-type concentrator, according to the GOST 9454-78 and GOST 6996-66. Hardness measurement for formed metal was conducted using hardness meter HBR-VU-187 in accordance to the GOST 9012-59. Plotting of the detail was carried out by lines, with interval $5 \mathrm{~mm}$ between these lines.

\section{Obtained results}

The walls of C-Mn-Si composition (Fig. $1 c$ and $1 d$ ), formed via WAAM process in carbon dioxide and gas mix, did not manifest any cracks, pores and other defects during visual observation. These walls were visually observed after

\begin{tabular}{|c|c|c|c|c|c|c|c|c|c|c|}
\hline \multirow{2}{*}{ No. } & \multirow{2}{*}{$\begin{array}{l}\text { Regulatory } \\
\text { document }\end{array}$} & \multicolumn{9}{|c|}{ Content of elements, \% } \\
\hline & & C & $\mathrm{Si}$ & $\mathrm{Mn}$ & $P$ & S & $\mathrm{Cr}$ & Mo & $\mathrm{Ni}$ & Al \\
\hline 1 & $\begin{array}{c}\text { Wire } \\
\text { GOST 2246-70 }\end{array}$ & $0.05-0.11$ & $0.7-0.95$ & $1.8-2.1$ & 0,03 & 0.025 & $\leq 0.2$ & $0.2-0.4$ & $\leq 0.25$ & $\leq 0.001$ \\
\hline 2 & Actual wall & 0.067 & 0.754 & 1.87 & $0 ., 03$ & 0.025 & 0.0079 & 0.015 & 0.005 & 0.001 \\
\hline 3 & $\begin{array}{c}\text { Steel 09G2SA } \\
\text { GOST 19281-2014 }\end{array}$ & $\leq 0,12$ & $0.5-0.8$ & $1.3-1.7$ & 0.03 & 0.035 & $\leq 0.30$ & - & $\leq 0,30$ & - \\
\hline
\end{tabular}



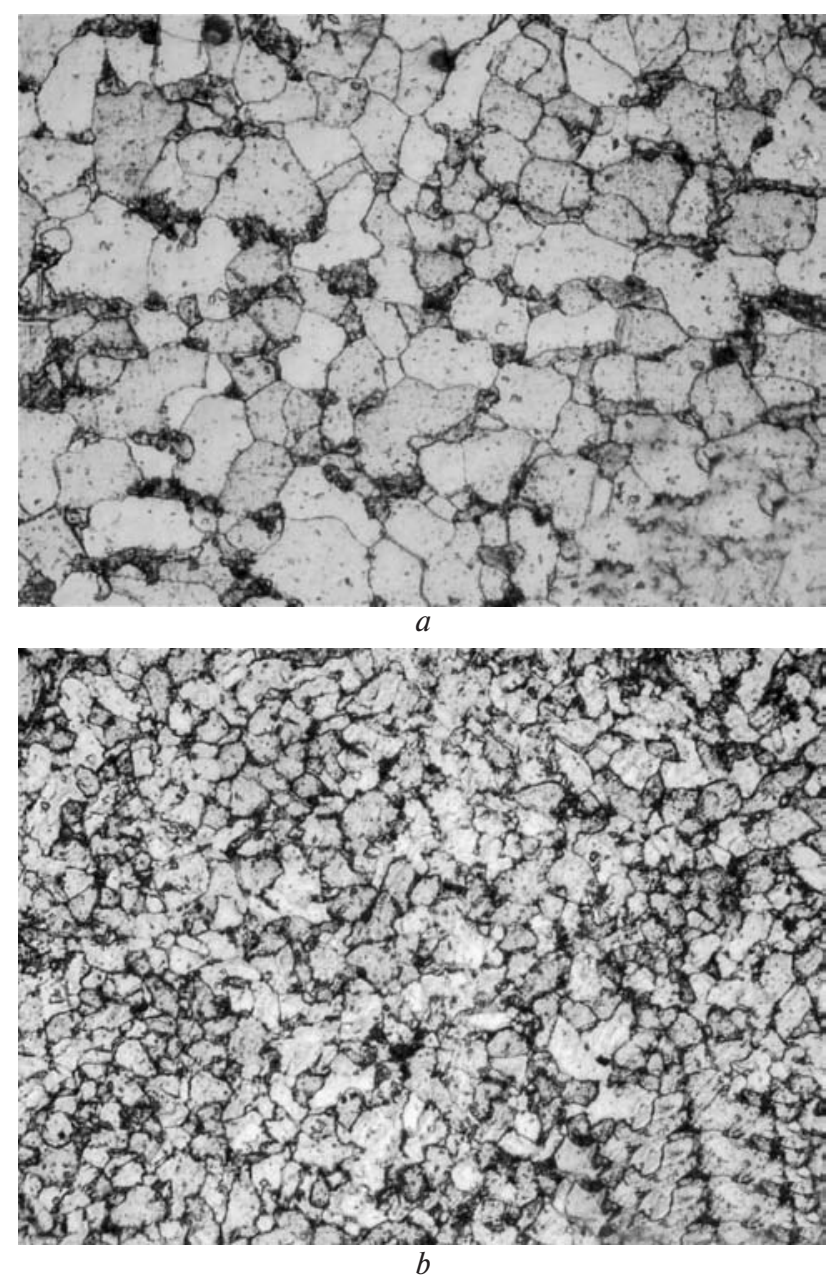

Fig. 2. Structure of 09G2SA steel ( $a$ ) and of formed wall of C-Mn-Si composition (b)

mechanical processing with use of 5 fold magnifying glass, and no defects (such as pores or incomplete fusion) were revealed. Chemical composition of the metal semiproduct of C-Mn-Si composition formed via additive technology is presented in the Table 1. Small difference in manganese content can be seen, other parameters of chemical composition are the same.

It is known [21, 22], that metal cooling speed has a strong effect on forming the structural states of seam metal during welding. To evaluate structural and phase transformations in a thermal effect zone, the generalized factor of the main welding parameters (such as electric current, arc voltage, welding speed) is used in the form of heat input. Metal cooling speed of the faced roll can be evaluated as relationship of weld heat input (Table 2); it is realized using the

\begin{tabular}{|c|c|c|}
\hline \multicolumn{3}{|l|}{$\begin{array}{l}\text { Table 2. Influence of weld heat input and cooling time on metal } \\
\text { cooling speed }\end{array}$} \\
\hline Heat input $\mathrm{Q}_{\mathrm{i}}, \mathrm{kJ} / \mathrm{mm}$ & $\begin{array}{c}\text { Cooling time } \\
\mathrm{t}(800-500), \mathrm{s}\end{array}$ & $\begin{array}{c}\text { Cooling speed, } \\
\mathrm{V}(800-500),{ }^{\circ} \mathrm{C} / \mathrm{s}\end{array}$ \\
\hline 3,18 & 20 & 12 \\
\hline 1,74 & 11,4 & 35 \\
\hline 1,35 & 8,9 & 39 \\
\hline 1,18 & 7,8 & 42 \\
\hline 1,05 & 6,9 & 51 \\
\hline
\end{tabular}

known empiric relationship, which was presented in the work [23]: $\log t(800-500)=0.626+0.214 \cdot \mathrm{Qi}$, where $t(800-500)$ is time of seam metal processing within the temperature range of minimal austenite stability, s; $Q_{i}$ is weld heat input, $\mathrm{kJ} / \mathrm{mm}$. Decrease of weld heat value (Table 2) promotes efficient rise of seam metal cooling speed to $50^{\circ} \mathrm{C} / \mathrm{s}$ and allows (in correspondence with the diagram) to provide decomposition of overcooled austenite in the area of ferrite-bainite transformation [22,23].

The coarse-grain ferrite structure of 09G2SA steel strip is presented on the Fig. 2a; pearlite impregnations are seen on the grain boundaries. The fine-grain ferrite structure of the wall of C-Mn-Si composition formed via WAAM process is presented on the Fig. $\mathbf{2 b}$. It can be described as polygonal equiaxial isomorphic ferrite, a kind of primary ferrite which is forming both inside former austenite areas and near the boundaries of grains and crystallites, at low cooling speed, when diffusion transformation occurs at high temperatures. Grains of polygonal ferrite have approximately equiaxial (polyhedral) form and smooth grain boundaries.

Hardness distribution through cross section of $\mathrm{C}-\mathrm{Mn}-\mathrm{Si}$ composition formed via WAAM process using protective gas $\mathrm{CO}_{2}$ and gas mix $\left(\mathrm{Ar}+\mathrm{CO}_{2}\right)$ is presented on the Fig. 3 . Hardness plotting displays non-uniform distribution in the case of carbon dioxide, with the areas of low and high metal hardness of C-Mn-Si composition. In the case of gas mix use, non-uniform hardness distribution during plotting decreases and is located within the narrow range of values 160-163 HB.

The results of testing for static extension are presented in the Table 3 and Table 4 . The series of samples (3 samples in

\begin{tabular}{|c|c|c|c|c|c|c|}
\hline \multicolumn{7}{|c|}{ Table 3. Preparation of samples for static extension testing } \\
\hline \multicolumn{4}{|c|}{ Measurements of samples before testing } & \multirow{2}{*}{\begin{tabular}{|c}
$\begin{array}{c}\text { Measurements } \\
\text { of samples } \\
\text { after testing }\end{array}$ \\
$\begin{array}{c}\text { Calculated } \\
\text { length, } \mathrm{L}_{1} \mathrm{~mm}\end{array}$
\end{tabular}} & \multirow{2}{*}{$\begin{array}{l}\text { Load } \\
\text { corresponding } \\
\text { to yield } \\
\text { strength, kgf }\end{array}$} & \multirow{2}{*}{$\begin{array}{l}\text { Load } \\
\text { corresponding } \\
\text { to tensile } \\
\text { strength, kgf }\end{array}$} \\
\hline $\begin{array}{l}\text { Seal (No.) } \\
\text { of sample }\end{array}$ & $\begin{array}{l}\text { Working cross } \\
\text { section of the } \\
\text { sample, mm }\end{array}$ & $\begin{array}{c}\text { Calculated } \\
\text { length, } L_{0} \mathrm{~mm}\end{array}$ & $\begin{array}{c}\text { Square of } \\
\text { cross section, } \\
\mathrm{F}_{0}, \mathrm{~mm}^{2}\end{array}$ & & & \\
\hline 1 & $9.7 \times 5.05$ & 40 & 48.98 & 46.7 & 1820 & 2370 \\
\hline 2 & $9.7 \times 5.10$ & 40 & 49.47 & 53.3 & 2040 & 2590 \\
\hline 3 & $9.85 \times 3.8$ & 35 & 37.43 & 46.8 & 1300 & 1700 \\
\hline
\end{tabular}

The limit of allowable error of measurement and recording of deformation didn't exceed $\pm 2.0 \%$ of the upper limit of the range of deformation measuring device, according to the GOST 28840-90. 
each) are characterized by the following conditions: No. 1 includes samples of manual additive technology in carbon dioxide, No. 2 includes samples of manual additive technology in gas mix, No. 3 includes robotized additive technology in carbon dioxide. It can be seen that mechanical properties of the samples from No. 2 series (in gas mix) are higher in comparison with samples in carbon dioxide. The comparative results of testing of 09G2SA steel sam-
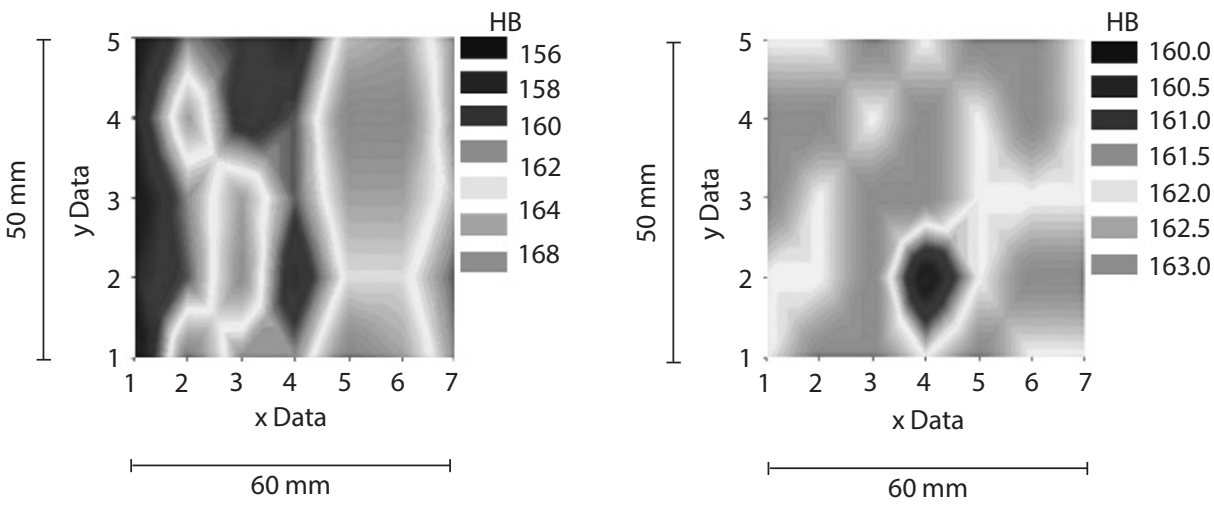

Fig. 3. Hardness plotting through cross section of $\mathrm{C}-\mathrm{Mn}$-Si composition obtained using protective gas $\mathrm{CO}_{2}(a)$ and gas mix $\left(\mathrm{Ar}+\mathrm{CO}_{2}\right)(b)$

ples and standard (GOST)

requirements are presented in the Table 4.

It is seen that metal mechanical properties of C-Mn-Si composition obtained via additive technology are higher. It should be noted that the samples of C-Mn-Si composition, which

were formed in carbon dioxide, had internal defects (pores) in the destruction area; however, their mechanical properties are higher in comparison with 09G2S steel samples (obtained via conventional metallurgical technology). The results of impact

\section{Table 4. Results of static extension testing}

\begin{tabular}{|c|c|c|c|c|}
\hline \multicolumn{6}{|l|}{ Table 4. Results of static extension testing } \\
\hline $\begin{array}{c}\text { Seal (No.) of } \\
\text { sample }\end{array}$ & $\begin{array}{c}\text { Testing } \\
\text { temperature, }{ }^{\circ} \mathrm{C}\end{array}$ & $\begin{array}{c}\text { Yield strength, } \sigma_{\mathrm{T}} \\
\left(\sigma_{0.2}\right) \mathrm{MPa}\end{array}$ & $\begin{array}{c}\text { Tensile strength, } \\
\sigma_{\mathrm{B}}, \mathrm{MPa}\end{array}$ & $\begin{array}{c}\text { Relative } \\
\text { elongation, } \delta_{5} \\
\left(\delta_{10}\right), \%\end{array}$ \\
\hline 1 & 20 & 364 & 474 & 16.75 \\
\hline 2 & 20 & 404 & 513 & 33.25 \\
\hline 3 & 20 & 340 & 445 & 33.71 \\
\hline $\begin{array}{c}\text { Steel 09G2S } \\
\text { (GOST) }\end{array}$ & 20 & 265 & 430 & 21 \\
\hline $\begin{array}{c}\text { Steel 09G2S } \\
\text { (Actual) }\end{array}$ & 20 & 435 & 22 \\
\hline
\end{tabular}

The limit of allowable error of measurement and recording of deformation didn't exceed $\pm 2.0 \%$ of the upper limit of the range of deformation measuring device, according to the GOST 28840-90. toughness testing of the samples are presented in the Table 5. There is no joint association between KCU and KCB due to different stressed state in Mesnager and Charpy samples and different input of bending work [24].

It is known that the same values of tensile strength and KCU of the same steel can be obtained after its various heat treatment, but KCV values will be rather different [24]. Fractography of fractures of C-Mn-Si compositions, which were manufactured via additive technology using carbon dioxide and gas mix, displays on tough pit type of destruction (Fig. 4).

Taking into account, that Mesnager sample is more sensitive to brittleness caused by weakening of grain boundaries,

\begin{tabular}{|c|c|c|c|c|c|c|c|}
\hline \multicolumn{8}{|c|}{ Table 5. Results of impact bending testing } \\
\hline \multirow[b]{2}{*}{$\begin{array}{l}\text { Seal (No.) } \\
\text { of sample }\end{array}$} & \multirow{2}{*}{$\begin{array}{c}\text { Testing } \\
\text { temperature, } \\
{ }^{\circ} \mathrm{C}\end{array}$} & \multicolumn{3}{|c|}{ Geometrical dimensions of the sample } & \multirow{2}{*}{$\begin{array}{c}\text { Destruction } \\
\text { work (KU), } \\
\mathrm{kg} \cdot \mathrm{cm}\end{array}$} & \multirow{2}{*}{$\begin{array}{c}\text { Impact } \\
\text { toughness, } \\
(\mathrm{KCU}) \mathrm{J} / \mathrm{cm}^{2}\end{array}$} & \multirow[b]{2}{*}{ Appendix } \\
\hline & & Width, mm & $\begin{array}{l}\text { Height, mm (in } \\
\text { the place of notch } \\
\text { application) }\end{array}$ & $\begin{array}{l}\text { Square of cross } \\
\text { section, } \mathrm{cm}^{2}\end{array}$ & & & \\
\hline 4 & 20 & 9.95 & 7.94 & 0.790 & 15.6 & 193.5 & \multirow{2}{*}{ Facing in $\mathrm{CO}_{2}$} \\
\hline 5 & 20 & 9.94 & 7.9 & 0.785 & 14.8 & 184.7 & \\
\hline 6 & 20 & 10.01 & 7.92 & 0.792 & 21.5 & 265.7 & \multirow{2}{*}{$\begin{array}{c}\text { Facing in gas } \\
\text { mix }\end{array}$} \\
\hline 7 & 20 & 9.96 & 7.95 & 0.791 & 21.2 & 262.3 & \\
\hline $\begin{array}{l}\text { Steel 09G2S } \\
\text { (GOST) }\end{array}$ & 20 & & & & & $\geq 59$ & \\
\hline $\begin{array}{l}\text { Steel 09G2S } \\
\text { (Actual) }\end{array}$ & 20 & & & & & 115 & \\
\hline
\end{tabular}

Impact toughness (KCU) of metal, which was formed via additive technology, was determined by impact bending testing of the samples with U-type concentrator, in accordance to the GOST 9454-78 and GOST 6996-66, with the error within \pm 0.05 mm. 

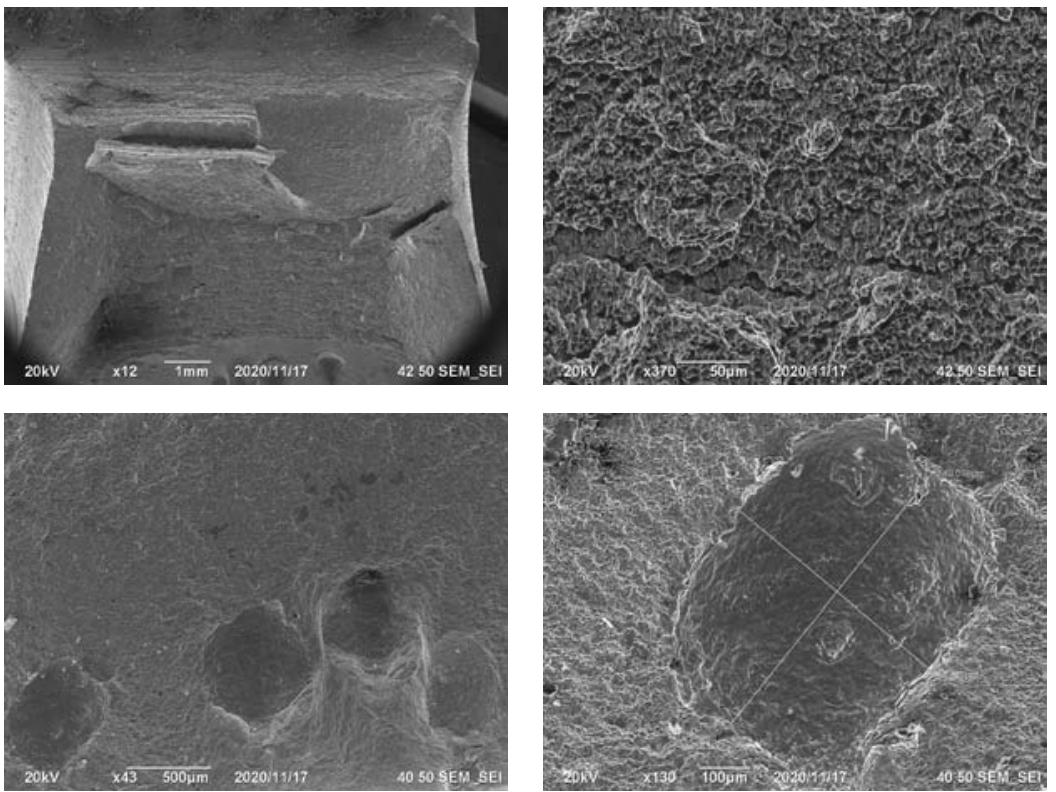

Fig. 4. Electron microscope pictures of fracture surfaces in the samples formed of compositions using carbon dioxide

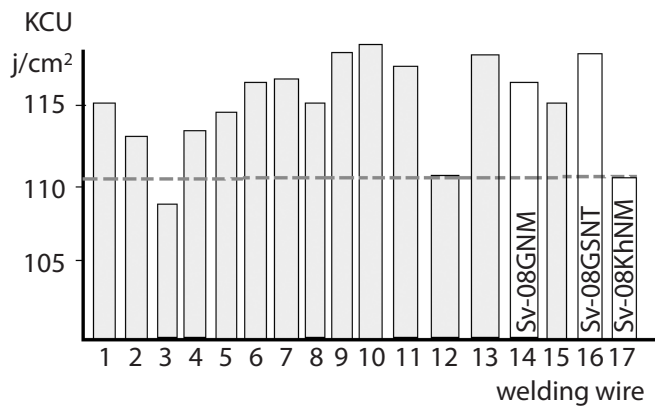

$a$

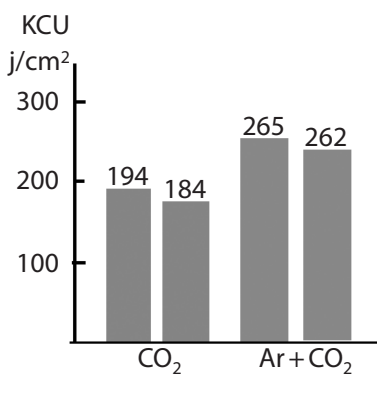

$b$
Fig. 5. Comparison of impact toughness of faced metal at $+20{ }^{\circ} \mathrm{C}$ for wire Sv-08G2S of different producers $(a)$ and via additive technology using various protective gases $(b)$; numeration of wires is presented in [25]

to lowering of resistance to brittle destruction, because a crack easily propagates along straight line in coarse ferrite grains, until it varies its direction from a grain boundary. Dominating microstructure of each center of a faced roll, consisting of typical fine-dispersed multi-angular ferrite $(\mathrm{F})$ as a primary phase, and small amount of fraction of lamellar pearlite $(\mathrm{P})$, which is mainly formed along ferrite grains boundaries, is presented on the Fig. $2 b$. It should be noted, that the above-mentioned microstructural features were observed in all layers of the component from lower to upper wall area. To provide qualitative evaluation of volumetric part of pearlite phase, which is forming along ferrite grains boundaries, the detailed analysis of the microstructure image was conducted using ImageJ software; this image was taken from different sections of the sample. Volumetric part of pearlite phase was approximately equal to only $10.54 \pm 0.46 \%$ from total microstructure due to low carbon content in initial wire $(0.06-0.15 \%)$. Pearlite component in the seam metal structure is located mainly on joints of ferrite grains boundaries, while size of pearlite parts varies from 3 to $10 \mu \mathrm{m}$. Additionally, presence of carbide-type particles with size of $0.5-1.8 \mu \mathrm{m}$ is noted inside ferrite grains. Grain size is considered as one of the most important microstructural characteristic having the effect on mechanical properties. Coarsening of grains in the thermal effect zone of previously applied facing roll (one layer facing) is observed with the average grain size $18.56 \pm 2.32 \mu \mathrm{m}$, while the grain size in the area inside the roll is rather smaller $(4.96 \pm 1.24 \mu \mathrm{m})$. Taking into account the features of layer-by-layer deposition, which is connected with WAAM method, each ap-

segregation banding and segregation heterogeneity [24], KCU evaluation of faced metal was conducted in this work. Impact toughness of the samples, which were obtained using gas mix, is higher than that using carbon dioxide. At the same time, impact toughness of the samples of 09G2S standard steel is rather lower in comparison with the metal of C-Mn-Si composition, manufactured via additive technology. If this composition is obtained using carbon dioxide, its fracture cross section has large pores, what had influence on the results of testing for static extension and impact toughness.

\section{Discussion of the results}

The results of the research show that metal of C-Mn-Si composition, which was formed via the new WAAM process, is characterized by the complex of high mechanical properties in comparison with metal obtained via conventional metallurgical technology. Mechanical properties are determined not only by manufacturing method, but also by metal structure. It is known [22, 23], that excessive amount of polygonal ferrite leads plied layer heats the previous one repeatedly. The resulting high temperature in previously solidified path will promote migration of grains boundaries and, respectively, causes enlargement of grains near each boundary of melt bath. Such microstructural heterogeneities in the structure of printing component can have negative effect on mechanical properties of this component and promote anisotropic mechanical properties. At present time, many scientists have carried out researches of the metal forming mechanism via WAAM method as well as microstructure and characteristics of many kinds of metal materials (especially metal materials which are hardly subjected to forming using conventional processing methods), such as Ti6Al4V, Inconel 625, AA5183 and AZ91D. Deposited material is subjected to many thermal cycles during forming of WAAM billet; it results in forming of different grain structures in various layers along deposition direction, what determines billet mechanical properties. Typical WAAM billet consists of many radial-columnar grains, which were grown epitaxially from substrate and located in the direction of laying, perpendicular to the solidus-liquidus boundary with maximal temperature gradient. In this case, 
the order of laying of facing rolls, heat input and parameters of welding procedure have direct effect on the form, geometrical dimensions, melting depth and number of rolls, as well as on size and morphology of structural components, percent relationship of cast and recrystallized metal seam microstructure. Fig. 5 presents the results of comparison of impact toughness values of welding wire Sv-08G2S from different producers and the metal of C-Mn-Si composition formed by welding wire Sv-08G2S via WAAM method. The data on impact toughness were taken from the work [25].

It can be seen that $\mathrm{C}-\mathrm{Mn}$-Si composition metal, formed by $\mathrm{Sv}-08 \mathrm{G} 2 \mathrm{~S}$ wire via WAAM method, is characterized by high impact toughness values.

The conditions providing increase of mechanical properties were established on the base of conducted research of protective gas influence on forming of properties structure in s composition metal cross section. Protective gas plays an important role in WAAM processing, e.g. for rise of welding wire melting speed, for spattering control and for slag decrease after welding. Protective gas has also serious effect on mechanical properties of formed component.

\section{Conclusions}

1. Relationship between shape, geometrical dimensions of facing rolls and percent content of recrystallized structure in cross section of $\mathrm{C}-\mathrm{Mn}$-Si composition metal, formed via the new WAAM process is shown. This structure is characterized by the complex of high mechanical properties in comparison with metal manufactured via conventional metallurgical technology.

2. It was established that yield strength and tensile strength of C-Mn-Si composition metal, formed via the new WAAM process exceed the typical values of 09G2S deformed metal. There is small anisotropy of yield strength and tensile strength, which is connected with use of various compositions of protective gases.

3 . It is shown that correlation between cast and recrystallized structure has direct effect on mechanical properties. If the part of recrystallized structure formed in cross section of seam metal makes about 45-56 \%, high impact toughness values of $\mathrm{C}-\mathrm{Mn}$-Si composition are provided in comparison with metal manufactured via conventional metallurgical technology.

\section{REFERENCES}

1. ASTM Committee F42 on Additive Manufacturing Technologies. Standard terminology for additive manufacture-general principles and terminology. ISO/ASTM52900-15. 2009.

2. Gu D. D., Meiners W., Wissenbach K., Poprawe R. Laser additive manufacturing of metallic components: materials, processes and mechanisms. International Materials Review. 2012. 57 (3) : 133-16.

3. Ngo T. D., Kashani A., Imbalzano G., Nguyen K. T., Hui D. Additive manufacturing (3D printing): a review of materials, methods, applications and challenges. Composites Part B: Engineering. 2018. Vol. 143. pp. 72-196.

4. Gu D. D., Ma C. L. In-situ formation of Ni4Ti3 precipitate and its effect on pseudoelasticity in selective laser melting additive manufactured NiTi-based composites Applied Surface Science. 2018. Vol. 441. pp. 862-870.
5. Phan M. A. L, Fraser D., Gulizia S., Chen Z. W. Horizontal growth direction of dendritic solidification during selective electron beam melting of a Co-based alloy. Materials Letters. 2018. Vol. 228. pp. 242-245.

6. Williams S. W., Martina F., Addison A. C. Wire+arc additive manufacturing. Materials Science and Technology. 2016. Vol. 32. No. 7. pp. 641-647.

7. Ding D., Pan Z., Cuiuri D., Li H. Wire-feed additive manufacturing of metal components: Technologies, developments and future interests. International Journal of Advanced Manufacturing Technology. 2015. Vol. 81. pp. 465-481.

8. Pan Z., Ding D., Wu B., Cuiuri D., Li H., Norrish J. Arc welding processes for additive manufacturing: a review. Transactions on Intelligent Welding Manufacture. 2018. 3-24.

9. Shen C., Pan Z., Cuiuri D. Fabrication of Fe-FeAl functionally graded material using the wire-arc additive manufacturing process. Metallurgical and Material Transactions B. 2016. Vol. 47. No. 1. pp. 763-772

10. Rodrigues T. A., Duarte V., Miranda R. M., Santos T. G., Oliveira J. P. Current Status and Perspectives on Wire and Arc Additive Manufacturing (WAAM). Materials. 2019. Vol. 12. p. 1121.

11. Kargapoltsev S. K., Balanovsky A. E., Gozbenko V. E., Karlina Y. I., Karlina A. I. Possibility of obtaining complex form details using additive surface technology. IOP Conference Series: Materials Science and Engineering. 2020, Vol. 759. No. 1. 012011.

12. Balanovsky A. E., Osipov S. A., Shmakov A. K. Research of surface quality of structural components made using additive technology of electric arc welding. IOP Conference Series: Materials Science and Engineering. 2019. Vol. 632. No. 1. 012087.

13. Ge J. G., Lin J., Lei Y. P., Fu H. G. Location-related thermal history, microstructure, and mechanical properties of arc additively manufactured $2 \mathrm{Cr} 13$ steel using cold metal transfer welding. Materials Science and Engineering A. 2018. Vol. 715. pp. 144-153.

14. Hu Z. Q., Qin X. P., Shao T. Welding thermal simulation and metallurgical characteristics analysis in waam for $5 \mathrm{crnimo}$ hot forging die remanufacturing. Procedia Engineering. 2017. Vol. 207. pp. 2203-2208.

15. Artaza T., Alberdi A., Murua M., Gorrotxategi J., Frías J., Puertas G., Melchor M. A., Mugica D., Suárez A. Design and integration of WAAM technology and in situ monitoring system in a gantry machine. Procedia Manufacturing. 2017. Vol. 13. pp. 778-785.

16. Luo Y., Li J. L., Xu J., Zhu L., Han J. T., Zhang C. Y. Influence of pulsed arc on the metal droplet deposited by projected transfer mode in wire-arc additive manufacturing. Journal of Materials Processing Technology. 2018. Vol. 259. pp. 353-360.

17. Wu B. T., Pan Z. X., Li S. Y., Cuiuri D., Ding D. H., Li H. J. The anisotropic corrosion behaviour of wire arc additive manufactured Ti-6Al-4V alloy in 3.5\% NaCl solution. Corrosion Science. 2018. Vol. 137. pp. 176-183.

18. ShiX. Z., Ma S. Y., Liu C. M., Wu Q. R., Lu J. P., Liu Y. D., Shi W. T. Selective laser melting-wire arc additive manufacturing hybrid fabrication of Ti-6Al-4V alloy: Microstructure and mechanical properties. Materials Science and Engineering A. 2017. Vol. 684. pp. 196-204.

19. Zhang H., Wang X., Wang G. Hybrid direct manufacturing method of metallic parts using deposition and micro continuous rolling. Rapid Prototyping Journal. 2013. Vol. 19, No. 6. pp. 387-394.

20. Langger J., Schabhüttl P., Vuherer T. CMT additive manufacturing of a high strength steel alloy for application in crane construction. Metals. 2019. Vol. 9. No. 6. p. 650

21. Grabin V. F., Denisenko A. V. Metal science of welding of low- and medium-alloyed steels. Kiev : Naukova dumka. 1978. 276 p.

22. Shorshorov M. Kh., Belov V. V. Phase transformations and varying steel properties during welding. Moscow : Nauka. 1972. 219 p.

23. Evans G. M. The effect of heat input on the microstructure and properties of C-Mn all-weld-metal deposits. Welding journal. 1982. April. pp. 125-132.

24. Shtremel M. A. Information content of impact toughness measurements. Metallovedenie $i$ termicheskaya obrabotka metallov. 2008. No. 11. pp. 37-51.

25. Protopopov E. A. et al. Influence of chemical composition of welding wire Sv-08G2S on impact toughness of faced metal. Svarochnoe proizvodstvo. 2016. No. 10. pp. 3-8. 